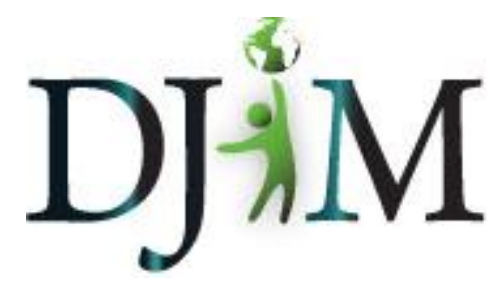

Volume 6 - Spring 2010 djim.management.dal.ca

\title{
Thrills, Chills, and Controversy: The Success of R. L. Stine's Goosebumps
}

\begin{abstract}
This paper investigates the popularity of and controversy surrounding R. L. Stine's Goosebumps series. The books were very popular with children in the 1990s, yet the fact that they are series novels and they belong to the horror genre led many parents, teachers, and librarians to blast the novels as inappropriate and even evil. Others felt that it was important that their children were reading, period. Controversy ensued when attempts were made to ban the books from public and school libraries and restrict children from reading them. Many parents were angered by the attempts at censorship and felt that their children had the right to read whatever they wanted. Throughout the years, Stine's novels became less popular, but they never disappeared, and children everywhere continue to get goosebumps.
\end{abstract}

About the Author: Nicole Tanner grew up in Hardwood Lands, a small rural community in East Hants, Nova Scotia. An avid reader from a young age, Nikki graduated from Saint Mary's University in 2008 with a BA (Hons) in English and completed an MA in English at Dalhousie in 2009. She is currently an MLIS candidate at Dalhousie and lives in Halifax with her partner Glenn and their two cats, Max Power and Simon Pegg-Lebon. 


\section{Introduction}

In the 1990s, R. L. Stine, a writer of horror novels for young adults, began publishing a series of horror stories for pre-teens called Goosebumps. The series was a success, as children everywhere became obsessed with the books, which spawned copious amounts of merchandise and even a television series (Jones, 1998). However, many people were horrified by the novels, which they deemed unwholesome and too frightening for children. The novels inspired a controversy in which parents, educators, and librarians were divided: many wanted the novels banned from schools and public libraries, while others thought that the novels should be praised for encouraging children, especially boys, to read (Jones, 1998). While the controversy surrounding the books eventually died down, and moralists shifted their attention elsewhere, Goosebumps and its subsequent spin-offs continue to bring enjoyment to children, who learn how fun and exciting reading can be.

\section{Protecting Innocence or Hindering Development?}

Attempting to censor and restrict the reading habits of children is not a new phenomenon. For centuries, many parents worried about their children reading fairy tales (Tucker, 1976). According to Tucker (1976), when the Grimm Brothers first published their fairy tales, they were intended as scholarly research and included footnotes for further reading. However, children loved the stories, "forcing reprint after reprint, as well as progressive modifications of the original stories in favour of a younger audience" (Tucker, 1976, p. 31). Prior to the Grimm Brothers' publication of these stories, Tucker (1976) claims that some people were concerned about the possible effects of children hearing fairy stories from servants or even their parents. The concern was that such stories did not set a good moral example and simply filled the heads of young children with magic and the supernatural rather than "useful reality" (Tucker, 1976, p. 32). One vocal critic of children hearing fairy tales is Mrs. Trimmer, who in 1803 argued that such stories "fill the heads of children with confused notions of wonderful and supernatural events, brought about by the agency of imaginary beings" (Tucker, 1976, p. 38). Mrs. Trimmer claimed that "the terrific images, which tales of this nature present to the imagination", are harmful to children because such images create "unreasonable and groundless fears" (Tucker, 1976, p. 38). Aside from the possibility of injuring the minds of children, Mrs. Trimmer also objected to the lack of moral instruction in the stories (Tucker, 1976).

It is not just fairy tales that many people have had problems with young people reading. According to Crawford (2008),

Dime novels, boys' adventures stories, horror, the Oz books, comics, and series fiction, were deemed "sensational literature," reading material thought to develop children's taste for the lurid and the fantastic. Numerous educational studies concluded that these books were "unwholesome" and 
"immoral." Children who read them were believed prone to juvenile delinquency, illiteracy, mental laziness, and disrespect for authority. (para.

3)

It was believed that children who read stories of the fantastic were doomed to a life of crime and vice. An opponent to this point of view is Dr. J. Langfeldt, who, in 1961, argued that the fear created by children due to reading fairy and folk tales aids in the development of courage (Tucker, 1976). If parents and educators prevent children from encountering things which rouse fear, they may hinder the children's natural development: "Just as the child must find courage to take its first steps away from its mother, so also it must learn to deal with other things which might cause it anxiety or fear" (Tucker, 1976, p. 61). Tucker (1976) argues that the imagination of a child is more powerful than any story, and that a child can imagine terrors equal to those described or pictured in a fairy tale. By reading about such horrors, children are able to better understand their fears, refer to them by name, and perhaps share their fears with others (Tucker, 1976). Thus, experiencing fear is an essential part of growing up.

\section{R. L. Stine and the Success of Goosebumps}

Prior to his success with Goosebumps, Stine wrote joke books and horror novels for young adults, including the successful Fear Street series (Jones, 1998). Fear Street is aimed at teenage readers and is written at a level in which maturity is required, and this is evident by how the novels contain both blood and death; as Stine himself has said, there is a high mortality rate in Shadyside, the town in which Fear Street is set (Jones, 1998). As Jones (1998) points out, the world of Fear Street is real, and the supernatural is rarely the cause of a character's death. There are many scenes that evoke disgust, including one character's discovery that her lunch bag is full of blood, and another character's vomiting due to the foul odour of a dead and decaying rat (Jones, 1998). The Fear Street series became very popular with teenagers and pre-teens were reading the books as well. This knowledge led Stine to develop a new series of horror novels, this time aimed at readers too young and immature to handle the realistic scares and violence of Fear Street (Jones, 1998). While the new novels would be scary, they would be less realistic: "no blood, no guts, no bullets, no guns" (Jones, 1998, p. 149). These novels would contain far less violence and more unrealistic elements, like monsters and other aspects of the supernatural (Jones, 1998). Stine's answer to this demand was Welcome to the Dead House, the first book in the Goosebumps series, which was published in 1992 (Jones, 1998).

Goosebumps was not an instant success. It was not until the third book that the series began to gain popularity, which Jones (1998) attributes to word of mouth: "As kids learned about the books, they told their friends, who told their friends" (p. 150). After the publication of the sixth book, Let's Get Invisible, the series entered Publishers Weekly's children's bestseller chart, and in 1994 books appeared on USA Today's bestseller list (Jones, 1998). The novels were released at a rate of one per month, and the series became so successful that it inspired 
several other products, including a television series, prime time and after-school specials, videos, t-shirts, pencil toppers, tattoos, board games, boxer shorts, key chains, compasses, rulers, and notebooks (Jones, 1998; Mesmer, 1998). Children everywhere were hooked on Goosebumps, but it did not take long for Stine's success to turn into controversy.

\section{The Great Goosebumps Debate}

Many parents, librarians, and educators supported children reading Goosebumps. Soares, whose granddaughter read the novels, argues that while the books have supernatural elements and put "children in a position of fright, danger, and loss of control" (Soares \& Tiede, 2002 , p. 176), they do not contain any real violence. The books do not contain blood, and there are never any incidents in which the characters are in danger from real-life sources such as kidnappers, burglars, or murderers. The danger in the novels is more apt to come from something that young readers know are not real, such as a live mummy, a ventriloquist's dummy, or a monster (Soares \& Tiede, 2002). While the stories are scary, Soares states, "the sources of the scares are so patently unreal that they cause more frisson than fear" (Soares \& Tiede, 2002, p. 176). Soares's granddaughter, Tiede, states that she is well aware that the novels are not real and that there is no threat that she or other children are experiencing too much fear or are harmed while reading (Soares \& Tiede, 2002).

Soares states that the novels teach children that it is acceptable to be afraid and that there is no shame in being considered a coward (Soares \& Tiede, 2002). Throughout the novels, other children constantly frighten the protagonist, who is then publicly humiliated. "These episodes cause a great deal of humiliation and, often, anger," Soares states (Soares \& Tiede, 2002, p. 179). Thus, one of the main fears found in the Goosebumps novels is the fear of others discovering one's cowardice. The narrators often admit to being cowards, which then reassures readers that it is all right to be afraid sometimes (Soares \& Tiede, 2002). As reading Goosebumps is fun, the novels show that being scared can sometimes be a fun experience and does not always have to be avoided (Soares and Tiede, 2002). Like Dr. Langfeldt argues that fairy tales promote the independence of children, Soares and Tiede (2002) claim that the novels help children work through some of the problems and fears that they encounter in their lives.

The novels do not contain illustrations; thus, children are forced to use their imaginations while they read. Soares argues that this is reason enough to allow children to read the books:

I suspect that Goosebumps, and other series like them, are the first nonillustrated books that many children read, preparing them for more serious reading later-and proving to them that words on a page really do have the power to stir the imagination. (Soares \& Tiede, 2002, p. 177) 
The ability of children to vividly picture the scenes that they are reading in Goosebumps will allow them to exercise their minds and imaginations enough to draw them to other novels when they grow up and out of Goosebumps. Many children who read the series claim that the novels are so engaging and contain so many details that they feel like they are personally involved in the stories and experiencing what the protagonists experience (Mesmer, 1998). One child said that as she was reading one particular novel about killer bees, she felt as if the bees were all over her (Mesmer, 1998). It is obvious that the imaginations of those who read Goosebumps are exercised to a great extent, and in the future they may seek the same exercises with other novels.

Not everyone agreed with such positive views of the Goosebumps series. Some parents, teachers, and librarians blasted the novels, and some went so far as to claim that the books were "from the devil" (Stepp, 1997). One man, parent Victor Williams, argued that children are defenceless against the more sinister aspects of the novels and that reading them will "get them interested in evil, wicked things" (Stepp, 1997). Williams claimed that the novels "spell out formulas for witchcraft and occultism" (Stepp, 1997, para. 12). Soares responds to such claims with a tone of gentle mockery and states that "it is difficult to construe the few magic spells and incantations found in this book as satanic. They are about as satanic as 'abracadabra!" (Soares \& Tiede, 2002, p. 180). Campbell believes that Stine is "wicked" and "extremely destructive," and she likens the author to a predator who "preys on the absolute worst instincts of the human soul" (Hill, 1996, para. 54). Campbell likens Stine's books to pornography, because readers "get a physical rush from reading them. It's not necessarily sexual, but it's visceral" (Hill, 1996, para. 55). Williams "cringed when he saw the book jackets with "hideous things like werewolves, ghosts, blood, vampires and all kinds of gory stuff"' (Stepp, 1997, para. 12). As Soares states, there is no blood in the books (Soares \& Tiede, 2002); therefore, the gore Williams attributes to the novels is imagined. Williams has judged the entire series incorrectly based upon one book's cover.

Mesmer (1998) points out, however, that there are children's books not condemned by parents, educators, and librarians that contain much more violence than the Goosebumps series. Many children's book writers place violent episodes in their books in order to "bring power and authenticity to their works" (Mesmer, 1998, p. 112); for example, Mesmer (1998) refers to Fox's 1972 award-winning novel The Slave Dancer, which includes a graphic description of a slave being shot after he is beaten and bound as blood pours down his back (Mesmer, 1998). Mesmer (1998) juxtaposes this scene with an excerpt from Stine's Legend of the Lost Legend, which contains no blood or viscera; rather, the scene is about children who are being overrun by mice. Mesmer (1998) argues that Fox's use of violence is acceptable for children, although it is far more graphic, because Fox is describing historically accurate events and in the process shows the immorality of slavery. The violence in Stine's novels, however, has no purpose: 
Stine's reader experiences chaos. The lack of a logical pattern leads the reader to believe that humans have no role in perpetuating or stopping violence.... In this setting, violence becomes hyper-real...or removed from consequence, pattern, empathy, or human control. (Mesmer, 1998, p. 113)

Thus, Fox's readers will learn a moral from the novel and not simply be entertained, whereas Stine's readers learn nothing of ethical value. Stine prefers it that way, however, and he argues that people of all ages read horror literature to "escape rationality" (Stine, 1998, p. 2), not to learn lessons or morals. According to Jones (1998), Stine is proud that his novels have no morals, and thus are ways for children to escape the rationality of their own lives.

Another issue parents had with the series is the portrayal of the characters. According to Jones, the children in the novels are normal kids who are

not cute or precocious, in fact they are insufferable in their selfishness...Rather than presenting children in fiction as parents and teachers would like them to be, Stine presents kids as they sometimes can be. Kids may say the funniest things, but they can also say some of the nastiest. (1998, p. 159)

Portraying children acting like children makes the novels more realistic. In the real world, not every fearful experience produces a moral. Nodelman, a university English professor who does not condemn the series, states that the novels "represent what we really believe and how we really act" (Hill, 1996, para. 50). However, Nodelman also criticizes their lack of moral framework: "being good or bad has nothing to do with how things turn out. So what you get is a sense that the world is a random place. I find them morally reprehensible" (Hill, 1996, para. 50). Rather than teaching his readers a moral lesson, Stine is "simply trying to confirm their suspicions that the world is indeed a scary place" (Hill, 1996, para. 50).

Many parents and educators worry that if children read Goosebumps they will never move on to "real literature" and will subsist on a diet of Stephen King and other horror novelists, as if a generation of horror fans would destroy the moral fibre of society. Campbell likens the process to "eating cotton candy and potato chips all the time. After a while, you lose your taste for anything nourishing" (Hill, 1996, para. 56). Critics like Jones (2001) take offence to remarks like Campbell's, and Jones argues that Stine, like King, is a great entertainer and gifted storyteller who "knows how to keep readers interested and involved, and, most important, how to satisfy them" (p. 4). Besides, Jones (2001) notes, King's novels are much more challenging than Goosebumps books, so children who move onto King are exercising their minds further.

Aside from the horror elements, many people object to Goosebumps because it is a series, and series novels are deemed less intellectually stimulating than other novels or pieces of great literature. Series fiction is known for its formulaic and predictable plots and endings; however, Jones (2001) argues that that is the reason they are popular: "Consumers know 
exactly what they are getting and they expect it...Once a reader learns and likes a series, they know they can trust it" (p. 16-17). Nevertheless, loyalty toward a series will not prevent a reader from branching out and investigating new titles. Nodelman argues that reading series literature will not hinder a child's ability to move on to more demanding and serious novels, as he knows "many people who have become ardent readers of serious literature as adults [who] spent part of their childhood absorbing every book in a popular series" (Hill, 1996, para. 49).

One common complaint about Goosebumps is that the series is not well written. Campbell states that Stine is "an extremely bad writer," and suggests that if the author were to submit his stories as a fifth grade essay "he would get a D minus" (Hill, 1996, para. 54). This view is prevalent even among Stine's supporters. McGillis (1995-96) describes the books as "camp" because "they are so artificial, so formulaic, so predictable, so repetitive, so bad" (p. 15); and Nodelman states that the novels are "not great literature . . . but they're better written than some of the other popular series, like 'The Baby-Sitters Club'" (Hill, 1996, para. 51). However, remember that these novels are written for children, and thus they do not need to be as well written as a Dickens novel, for example, for children to enjoy them. The level at which they are written is intended to interest and engage young readers, not bore them with long-winded passages and confuse them with words that they cannot understand. Stine understands his audience, and this is vital to his success.

\section{Challenges and Censorship Attempts}

Many parents and school officials felt that they had to take their complaints about Goosebumps to the next level and attempt to ban children from accessing the books. The American Library Association (ALA) (2010a) lists the Goosebumps series as number sixteen on its list of 100 Most Frequently Challenged Books: 1990-2000. Becker and Stan (2002) state that the ALA are aware of forty-six challenges concerning the Goosebumps series up to and including 1997, over seventy-five percent of which occurred in school libraries; however, that number is probably much higher, as not all challenges are reported to the ALA. In Minneapolis, Minnesota, a mother attempted to have several Goosebumps novels removed from a school library because she considered the novels to be too scary and inappropriate for children; however, the book review committee, comprised of parents and teachers, denied her request and voted to keep the books (Becker \& Stan, 2002). Another challenge was made in Bay County, Florida, on the basis that the novels contain "satanic symbolism, demonic possession, and violence" (Becker \& Stan, 2002, p. 58). The novels were removed from a school in Parks, Arizona, after a child in the fourth grade had a nightmare after reading one of the books (Foerstel, 2002). A parent-teacher organization protested the removal of the books from the school's library because it was an act of censorship, so the school board decided to change its policy to allow only students in grades three through six to check out the books (Foerstel, 2002). The books were brought under review at an elementary school in Hernando, Mississippi, after a school board member voiced concerns about the books being included in 
the school's accelerated reading program because he felt that the books desensitized children to violence (Foerstel, 2002). At a board meeting addressing this issue, a large group of parents and children opposed the proposed ban, and one parent claimed that the board "was acting as a censor by telling the school that it would only receive money for its accelerated reading program if it removed Goosebumps" (Foerstel, 2002, p. 224).

Most libraries do not subscribe to the doctrine of in loco parentis, which is the idea that a third party, namely the library, should be required to prevent children from reading offensive material, such as horror novels (Jones, 1998). It is the responsibility of the parents to protect their children from material that they deem inappropriate. According to the ALA (2004), it is the duty of parents, guardians, and teachers to help children develop critical thinking skills by exposing them to many different types of experiences, and this includes reading novels that may be considered inappropriate by others:

Parents and teachers have a responsibility to prepare the young to meet the diversity of experiences in life to which they will be exposed, as they have a responsibility to help them learn to think critically for themselves. These are affirmative responsibilities, not to be discharged simply by preventing them from reading works for which they are not yet prepared. In these matters values differ, and values cannot be legislated; nor can machinery be devised that will suit the demands of one group without limiting the freedom of others. (ALA, 2004, para. 12)

This statement can certainly be applied to the attempts to ban Goosebumps. Many parents sought to simply shelter their children from things that might be offensive, frightening, or uncomfortable rather than allow the children to decide for themselves whether or not they could handle them. Wargo argues that parents should talk about the novels with their children because the books contain "occasional morals worthy of discussion" (Wargo \& Graham, 1997, p. 43), and she suggests that teachers get involved as well by conducting a unit on the horror genre that includes book reports and art projects. Nodelman states that teachers have a responsibility to discuss Goosebumps books with their students: "[T]eachers don't do enough in general about teaching literary strategies. They have an obligation to discuss these books with their students. Kids need some ways of thinking about them" (Hill, 1996, para. 52). It is through discussion of books like Goosebumps and other novels that many find offensive that a child's ability to think critically will be developed.

Aside from the development of critical thinking skills, the ALA (2004) sees attempts to censor or limit access to books as an attack on the freedom of others. It is the Association's belief that everyone is free to decide what he or she wants to read, regardless of whether or not some people find it offensive: 
In a free society individuals are free to determine for themselves what they wish to read...But no group has the right to take the law into its own hands, and to impose its own concept of politics or morality upon other members of a democratic society. Freedom is no freedom if it is accorded only to the accepted and the inoffensive. (ALA, 2004, para. 14)

Certainly parents have the right to influence what their children can or cannot read; however, when they go to a school or library setting and attempt to get the alleged offensive materials removed or banned, preventing other children from accessing the materials, they are limiting the freedom of those children to read what they choose. They are also limiting the freedom of the parents who allow their children to read the books. Not everyone agrees with the ALA's policy of intellectual freedom. Schlafly (1985) believes that the wishes of parents should be respected and that any material deemed offensive by parents should be removed from schools:

Schools should make every possible effort to avoid offending the religious, ethical, cultural or ethnic values of school children and their parents. Since presumably all educators would agree that Playboy and Penthouse magazines are not suitable reading materials for school children, it is clear that the issue over any particular book is one of appropriateness (which is a value judgment), not the First Amendment or 'academic freedom'. (p. 139)

Schlafly (1985) refers to the values of parents as the deciding factor in whether or not certain books should be banned; however, she neglects to regard the values of parents who do not believe in censorship. In her opinion, majority rules, and that can lead to dangerous situations in which censorship can get out of control.

While many parents were outraged by Stine's novels, many others were angered and offended by the attempts to ban or limit access to them. Pam Cohen took offence when her son's school prohibited its students from ordering Goosebumps novels from a book club. Cohen was angered that her ten-year-old son, already a fan of the series, was not allowed to order the books for his own personal reading: "It made me mad...I thought it was censorship" (Hill, 1996, para. 62). Cohen urged her son to order the books regardless of what his teacher told him; however, Cohen received a telephone call a few days later from the school's principal, who informed her that the books could not be ordered through the school. Cohen decided to go above the principal's head and contacted the president of the school board. Her persistence paid off, and her son was able to order the books (Hill, 1996). Like many parents, Cohen was thrilled that Stine was able to get children to read, and she did not feel that it mattered what he read as long as he was reading something. She claims that before her son discovered the Goosebumps series, "he didn't really read much at all. It was a struggle to get him interested in books" (Hill, 1996, para. 64). 
Ingham, a professor of Children's Literature, believes that Stine's books are "wonderful" and argues that they will not prove to be harmful to the children that read them; instead, she states, the real harm is in preventing children from reading Goosebumps: "Children are much brighter than we give them credit for. If left alone, they'll move on to something else. But if a parent pulls the book away, they may stop reading altogether" (Hill, 1996, para. 70). Ingham argues that it is important for teachers to know what children are reading, but it is important to not focus on what teachers think the children should be reading (Hill, 1996). Once more, Ingham believes that the importance lies in the fact that the children are reading: "As long as the child is reading, it doesn't matter what they're reading" (Hill, 1996, para. 70). Before Stine, it was often difficult to get boys to read; however, Goosebumps changed that, and boys were reading the novels as much as girls (Jones, 1998; Jones, 2001). According to Jones (2001), Stine wants his epitaph to say: "he got boys to read" (p. 19).

\section{The Declining, Yet Continued, Success of Goosebumps}

While Stine's books, and the associated controversy, dominated much of the 1990s, by 1997 the popularity of Goosebumps had peaked and sales began to decline (Jones, 1998). Goosebumps was so important to Scholastic, the series' publisher, that its stock dropped $40 \%$ due to the drop in sales (Jones, 1998). The decline of Goosebumps made front-page news, which, Jones (1998) states, "demonstrates the impact and importance of R. L. Stine. One writer, it seems, influences the fate of an entire company" (p. xxi). Perhaps in an effort to remedy this, Stine debuted Goosebumps 2000 in 1998. This series is intended to be scarier than Goosebumps (Jones, 1998), perhaps adapting to the interests and maturity levels of the fans of the original series. In 2008, another new Goosebumps series entitled Goosebumps: HorrorLand was released (Neary, 2008). Seventeen years have passed since the publication of his first Goosebumps title, but Stine is still encouraging children to read through his books, something in which he takes great pride: "Parents come up now and say, 'My kid never read a book in his life, and last night I caught him reading with a flashlight under the blankets.' ...I am very proud of that" (Neary, 2008, para. 16). Regardless of Scholastic's sales slump in 1997, Stine claims that "the books have sold all this time even when there were no new ones coming out" (Neary, 2008, para. 19). While the series may not be as popular as it was during its heyday, it has yet to die.

\section{Conclusion}

It is obvious that Stine's appeal to children was not simply a fad or trend in the 1990s but is based on his actual ability to entertain children. Regardless of one's opinion of series novels or the horror genre, one cannot deny the impact that Goosebumps has on encouraging young children to read. Attempts to restrict access to the books by parents and teachers did not hinder the success of the series and, perhaps, may have added to its appeal, as telling children that they cannot do something often makes them want to do it all the more (Wargo \& 
Graham, 1997). While parents seem to have moved on to objecting to other novels, such as J. K. Rowling's Harry Potter series, children have remained loyal to the novels, and new generations are being introduced to the scary, yet fun, world of Goosebumps. It is vital that librarians take notice of popular novels and series for young children and foster the burgeoning interest in these books, regardless of the themes of horror or the supernatural that the books might contain. Many parents and teachers will continue to object to books, or other popular media, that they deem offensive, such as the Harry Potter books or Justin Richardson and Peter Parnell's children's book And Tango Makes Three, which topped the ALA's (2010b, 2010c, 2010d) list of frequently challenged books in 2006, 2007, and 2008; in fact, the ALA (2010b) cites 513 challenged books in 2008 alone. It is important that librarians uphold the ALA's (2004) policies on censorship and cater to young readers to help ensure that they will continue to enjoy reading. As Jones (1998) states, "[t]he real horror is a culture where kids, especially boys, don't read-and Stine has done his best to stop that turn of the screw from happening in his lifetime" (Jones, 1998, p. 203). 


\section{References}

American Library Association. (2004). The freedom to read statement. Retrieved from http://www.ala.org/ala/aboutala/offices/oif/statementspols/ftrstatement/freedomreads tatement.cfm

American Library Association. (2010a). 100 most frequently challenged books: 1990-2000. Retrieved from http://www.ala.org/ala/issuesadvocacy/banned/frequentlychallenged/challengedbyde cade/1990_2000.cfm

American Library Association. (2010b). Top ten most frequently challenged books of 2008. Retrieved from http://www.ala.org/ala/issuesadvocacy/banned/frequentlychallenged/21stcenturychallenged/ 2008/index.cfm

American Library Association. (2010c). Top ten most frequently challenged books of 2007. Retrieved from http://www.ala.org/ala/issuesadvocacy/banned/frequentlychallenged/21stcenturychal lenged/2007/index.cfm

American Library Association. (2010d). Top ten most frequently challenged books of 2006. Retrieved from http://www.ala.org/ala/issuesadvocacy/banned/frequentlychallenged/21stcenturychal lenged/2006/index.cfm

Becker, B. C., \& Stan, S. M. (2002). Hit list for children: Frequently challenged books 2. Chicago \& London: American Library Association.

Crawford, P. C. (2008). A new era of gothic horror: A look at the subversive power of the genre and its appeal to today's teens. School Library Journal. Retrieved from http://www.schoollibraryjournal.com/article/CA6600683.html

Foerstel, H. N. (2002). Banned in the USA: A reference guide to book censorship in schools and public libraries $\left(2^{\text {nd }}\right.$ ed.). Westport \& London: Greenwood Press.

Hill, D. (1996). Who's afraid of R. L. Stine? Teacher Magazine, 7(6). Retrieved from Academic Search Premier database.

Jones, P. (2001). Nothing to fear: R. L. Stine and young adult paperback thrillers. Collection Management, 25(4), 3-23.

Jones, P. (1998). What's so scary about R. L. Stine? Lanham \& London: Scarecrow Press.

McGillis, R. (1995-96). R. L. Stine and the world of child gothic. Bookbird, 33(3-4), 15-21. 
Mesmer, H. A. (1998). Goosebumps: The appeal and predictability of violence. The New Advocate, 11(2), 107-118.

Neary, L. (2008). Goosebumps and guffaws in Stine's 'HorrorLand.' National Public Radio. Retrieved from http://www.npr.org

Schlafly, P. (1985). Libraries should reflect majority values. In T. O’Neill (Ed.), Censorship: Opposing viewpoints (pp. 138-140). St. Paul: Greenhaven Press.

Soares, S., \& Tiede, J. (2002). Goosebumps by R. L. Stine. In N. J. Karolides (Ed.), Censored books II: Critical viewpoints, 1985-2000. Lanham \& London: Scarecrow Press.

Stepp, D. R. (1997, May 14). Panel to decide book ban 2 Gwinnett parents alarmed over language, "the devil". The Atlanta Journal-Constitution. Retrieved from the Factiva database.

Stine, R. L. (1998). Lurking in the dark. Newsweek. Retrieved from http://www.newsweek.com

Tucker, N. (Ed.). (1976). Suitable for children? Controversies in children's literature. Berkley \& Los Angeles: University of California Press.

Wargo, S., \& Graham, A. (October 1997). Should kids read Goosebumps? NEA Today, 16(3), 43. 